\title{
ON THE PROBLEM OF PRIMARY DIAMOND SOURCES OF THE SOUTH-WESTERN SIBERIAN PLATFORM
}

\author{
KONSTANTIN N. EGOROV ${ }^{1}$, YURY V. MENSHAGIN, ALEXANDER P. SEKERIN ${ }^{1} \&$ DENIS A. KOSHKAREV ${ }^{1}$
}

\begin{abstract}
New data on the mineralogy of diamond-bearing varieties of deposits of different ages from the south-western Siberian platform (the Irkutsk amphitheater) are presented. Various genetic primary sources of diamond (effusive varieties of lamproitic rocks of the Australian type, kimberlitic bodies with minimum erosional truncation) are forecasted on the studied area. Practical recommendations for realization of mineralogical prospecting in the region are made.
\end{abstract}

Keywords: Siberian platform, kimberlites, lamproites, diamond.

The problem of exploration geology of the south-western Siberian platform concerning the relationships between diamond content of the present alluvium and regional bedrock sources still remains. Since the 1950's numerous findings of diamond in the Quaternary alluvial deposits within the Irkutsk region have stimulated geological prospecting and scientific research based on traditional notions of potential kimberlite sources. But kimberlites have not been found and researchers have suggested that diamonds and accessory minerals have undergone distant, prolonged and repeated transportation from areas situated far north of the considered region. Moreover picroilmenite, kimberlitic chrome-diopside and olivine are completely absent in the river valleys and tributaries, where the diamond-bearing placers have been found. Only rare pyrope grains occur here.

In recent decades the discovery of non-kimberlitic diamond sources (lamproites, alkaline basaltoids, picrites, metamorphites etc.) have complicated methods of prospecting for primary diamond-bearing deposits. In this situation data on the characteristics of indicator minerals from all concentrate and mineralogical associations available within the prospected area, along with the mineralogical peculiarities of different potential diamond sources should serve as a basis for evaluation of the diamond content of a certain area.

At present the highest diamond concentrations within the Chuna-Birusa region are found in modern deposits of the Tangui-Uda, Chuksha rivers and their tributaries (Fig. 1).

During diamond prospecting of past years 249 crystals with weights from 14 to $72 \mathrm{mg}$ (on average $33 \mathrm{mg}$ ) and one crystal of 2.5 carats have been found here (these average weights are from different samples and 33 is the average for all samples). The average weight of diamonds from placers of the region is overstated because crystals of $-1+0.5 \mathrm{~mm}$ in size were not extracted. Granulometric analysis of diamonds revealed a sharp predominance of crystals of $-2+1 \mathrm{~mm}$ in size; findings of larger crystals $(-8+4 \mathrm{~mm})$ are rare. Study of the crystallographic form of the diamonds showed that the rhombic dodecahedroid is most common, with lesser number of octahedroid. Crystals with cubic habit were not identified. In general diamonds are colorless (66.2-85.0\% - this range of values is for all studied samples); content of smoky-brown crystals varies from 7.5 to $14 \%$. Imperfect crystals among which

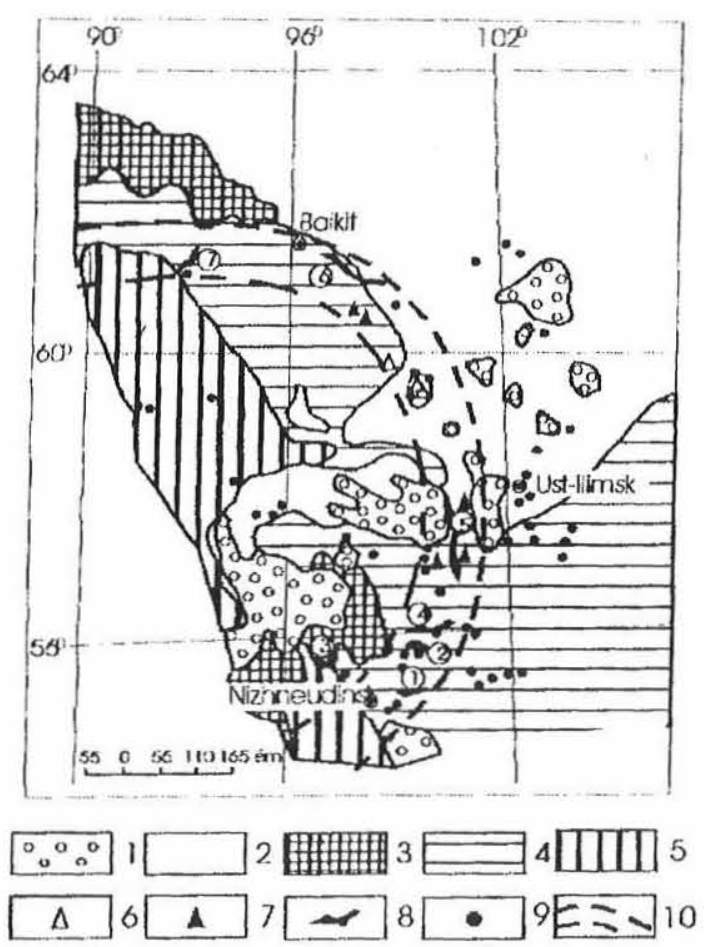

Figure I - Geologic-structural sketch map of the south-western Siberian platform showing the location of the diamondbearing placers. The structural stages: I - Mesozoic, 2 - Late Paleozoic, 3 - Middle Paleozoic, 4 - Early Paleozoic, 5 Precambrian; 6 - kimberlite pipes; 7 - hyperalkaline basic bodies; 8-diamond-bearing placers (numbers in circles): I Tangui-Uda, 2 - Andocha, 3 -Birusa, 4 - Chuksha, 5-Kova, 6-Tychano, 7-Velmo; 9-places of rare findings of diamonds in alluvium; 10 - Tychano-Uda diamondiferous area.

corroded and graphitized varieties constitute a significant portion, are not uncommon. Besides the percentage of diamonds with green and brown pigmentation spots (11\%), diamonds with graphite inclusions (up to $27 \%$ ) as well as 
corroded crystals $(13 \%)$ is quite high. It should be noted that the mineralogy of the Tangui-Uda and Chuksha diamondbearing placers is still poorly understood: in particular, there is no data on typochemistry of the accessory minerals of diamonds. In this paper new data on the detailed mineralogy of the diamondiferous terrace and alluvial deposits of the TanguiUda and Chuksha rivers as well as of the Lower Carboniferous pyrope-bearing Chuksha rock formation are given.

Pyropes occur in the form of round, round-flattened, and angular (up to fragments) grains from 0.2 to $1.0 \mathrm{~mm}$ in size with pale-lilac, purple and pink colors. The pyrope surfaces are often well polished, lustrous, and slight frosting on grains is less common. Pyropes with cuboid form and sculptured droplike tubercular surface occur in sediments of the Chuksha rock formation. Yellow-orange pyrope varieties are characterized by round to angular form with fragments of magmatogenic sculptures on the grain surfaces. Chrome spinels are 0.2-0.5 $\mathrm{mm}$ in size, more rarely up to $1 \mathrm{~mm}$ and have a round isometric form. Grains in the form of octahedra with smoothed edges and apexes are sometimes met.

The chemical data for magnesian chrome garnet-pyropes (content of pyrope component varies from 62.2 to $74.4 \mathrm{~mol} \%$ ) are given in Table 1 .

Pyropes are characterized by significant variations of $\mathrm{TiO}_{2}$ (from 0 to 0.92 wt \%), $\mathrm{Cr}_{2} \mathrm{O}_{3}$ (from 2.77 to $9.65 \mathrm{wt} \%$ ), very small variability of $\mathrm{CaO}$ (from 4.72 to $6.57 \mathrm{wt} \%$ ) and relatively narrow range of the $\mathrm{Fe} /(\mathrm{Fe}+\mathrm{Mg}$ ) ratio (from 13 to 20 mol.\%). From the ratio of $\mathrm{CaO}$ and $\mathrm{Cr}_{2} \mathrm{O}_{3}$ content in garnets on double Sobolev's plot the vast majority of analyzed pyropes lie in the field of lherzolite paragenesis (Fig. 2).

Three garnets from 40 chrome-magnesian pypopes are located in the domain of diamond dunite-harzburgite association. The peculiarity of pyrope chemistry is their high chrome content $(5.72 \mathrm{wt} \%)$ and low $\mathrm{Fe} /(\mathrm{Fe}+\mathrm{Mg})$ ratio (16 mol.\%). Some garnets contain minor amounts of $\mathrm{TiO}_{2}$ and at the same time they exhibit the high $\mathrm{Fe} /(\mathrm{Fe}+\mathrm{Mg})$ ratio $^{2}(20-18$ mol. \%). In contrast, others contain $\mathrm{TiO}_{2}$ more than 0.21-0.91 $\mathrm{wt} \%$ and at the same time they exhibit the low $\mathrm{Fe} /(\mathrm{Fe}+\mathrm{Mg})$ ratio (13-15 $\mathrm{mol} . \%)$.

Studied magnesian garnets are compositionally similar to pyropes from some types of mantle rocks. The majority of pyropes are similar to those from disaggregated and equigranular (protogranular) garnet lherzolites from kimberlites. Some pyrope grains may be compared with garnet from magnesian orthopyroxenites. According to Kharkiv et al. (1995) the general increased chrome content for pyropes from alluvium of the Chuksha and Tangui-Uda rivers (concentration

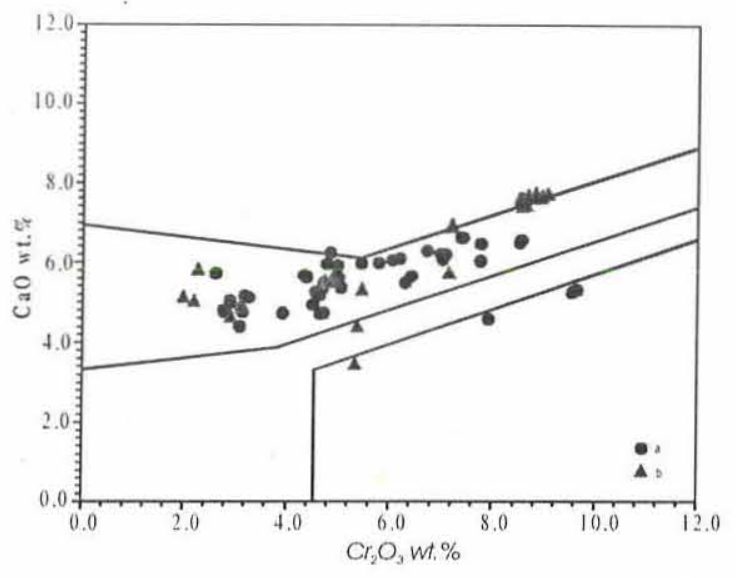

Figure 2 - Plot of $\mathrm{CaO}$ versus $\mathrm{Cr}_{2} \mathrm{O}_{3}$ contents for pyropes from alluvial deposits of the Chuksha and Tangui-Uda rivers (a) and diamond-bearing lamproites of the Sayan submontane region (b).

Table I - Chemical composition of magnesian chromic garnets from alluvial deposits of the Chuksha and Tangui-Uda rivers (wt \%)

\begin{tabular}{|c|c|c|c|c|c|c|c|c|c|c|c|c|c|c|}
\hline Oxides & I & 2 & 3 & 4 & 5 & 6 & 7 & 8 & 9 & 10 & 11 & 12 & 13 & 14 \\
\hline $\mathrm{SiO}_{2}$ & 42.22 & 42.21 & 41.96 & 42.18 & 41.77 & 41.62 & 41.96 & 42.32 & 41.93 & 42.58 & 42.05 & 41.96 & 40.47 & 40.10 \\
\hline $\mathrm{TiO}_{2}$ & 0.08 & 0.12 & 0.02 & 0.01 & 0.10 & 0.02 & 0.91 & 0.92 & 0.03 & 0.05 & 0.17 & 0.22 & 0.68 & 0.62 \\
\hline $\mathrm{Fe}_{2} \mathrm{O}_{3}$ & 0.54 & 0.59 & 0.60 & 0.57 & 0.67 & 0.45 & 1.90 & 2.24 & 0.93 & 0.97 & 1.13 & 1.03 & 0.83 & 0.74 \\
\hline $\mathrm{Al}_{2} \mathrm{O}_{3}$ & 21.57 & 21.32 & 21.04 & 21.21 & 19.65 & 19.87 & 18.57 & 18.49 & 21.10 & 21.13 & 18.41 & 18.65 & 17.53 & 17.46 \\
\hline $\mathrm{Cr}_{2} \mathrm{O}_{3}$ & 2.79 & 2.77 & 3.19 & 3.26 & 4.78 & 4.84 & 4.64 & 4.56 & 3.13 & 3.09 & 6.19 & 6.04 & 7.41 & 7.38 \\
\hline $\mathrm{MgO}$ & 20.30 & 19.89 & 19.33 & 19.40 & 18.53 & 18.53 & 20.12 & 20.38 & 21.16 & 20.78 & 19.32 & 19.49 & 19.23 & 19.22 \\
\hline $\mathrm{CaO}$ & 4.75 & 4.79 & 5.16 & 5.13 & 5.97 & 6.24 & 5.18 & 5.26 & 4.77 & 4.39 & 6.10 & 6.05 & 6.64 & 6.63 \\
\hline $\mathrm{MnO}$ & 0.39 & 0.38 & 0.46 & 0.48 & 0.50 & 0.50 & 0.30 & 0.28 & 0.33 & 0.29 & 0.39 & 0.42 & 0.38 & 0.39 \\
\hline $\mathrm{FeO}$ & 7.41 & 7.41 & 7.98 & 7.89 & 7.52 & 7.83 & 6.14 & 5.60 & 6.37 & 6.34 & 6.01 & 6.21 & 6.94 & 7.04 \\
\hline $\mathrm{Na}_{2} \mathrm{O}$ & 0.00 & 0.00 & 0.00 & 0.02 & 0.04 & 0.02 & 0.04 & 0.04 & 0.00 & 0.03 & 0.01 & 0.00 & 0.05 & 0.64 \\
\hline Total & 100.06 & 99.46 & 99.74 & 100.15 & 99.52 & 99.91 & 99.75 & 100.10 & 99.74 & 99.64 & 99.79 & 100.06 & 100.17 & 100.22 \\
\hline
\end{tabular}

\begin{tabular}{|c|cccccccccccccc|}
\hline Oxides & 15 & 16 & 17 & 18 & 19 & 20 & 21 & 22 & 23 & 24 & 25 & 26 & 27 & 28 \\
\hline $\mathrm{SiO}_{2}$ & 40.98 & 40.85 & 42.16 & 42.88 & 42.13 & 42.09 & 41.66 & 41.43 & 41.00 & 40.01 & 41.63 & 41.94 & 41.87 & 41.81 \\
$\mathrm{TiO}_{2}$ & 0.58 & 0.07 & 0.00 & 0.00 & 0.05 & 0.08 & 0.26 & 0.26 & 0.03 & 0.00 & 0.11 & 0.07 & 0.15 & 0.14 \\
$\mathrm{Fe}_{2} \mathrm{O}_{3}$ & 0.78 & 0.95 & 0.43 & 0.74 & 0.57 & 0.24 & 0.77 & 0.42 & 0.51 & 0.50 & 0.72 & 0.94 & 0.81 & 0.79 \\
$\mathrm{Al}_{2} \mathrm{O}_{3}$ & 16.40 & 16.34 & 21.73 & 21.39 & 20.31 & 20.26 & 20.25 & 20.48 & 18.58 & 18.80 & 17.07 & 16.82 & 19.85 & 19.82 \\
$\mathrm{Cr}_{2} \mathrm{O}_{3}$ & 9.55 & 9.65 & 2.89 & 2.89 & 4.34 & 4.39 & 4.72 & 4.70 & 7.08 & 6.98 & 8.52 & 8.55 & 4.65 & 4.71 \\
$\mathrm{MgO}$ & 20.16 & 20.15 & 19.96 & 19.76 & 19.14 & 19.12 & 21.43 & 21.53 & 19.84 & 19.70 & 18.79 & 18.59 & 20.12 & 20.10 \\
$\mathrm{CaO}$ & 5.26 & 5.32 & 4.98 & 5.05 & 5.68 & 5.64 & 5.49 & 5.36 & 6.20 & 6.23 & 6.50 & 6.58 & 4.72 & 4.73 \\
$\mathrm{MnO}$ & 0.38 & 0.37 & 0.48 & 0.47 & 0.44 & 0.43 & 0.27 & 0.22 & 0.42 & 0.42 & 0.41 & 0.42 & 0.48 & 0.45 \\
$\mathrm{FeO}$ & 6.54 & 6.45 & 7.53 & 7.17 & 7.59 & 7.61 & 5.25 & 5.53 & 6.51 & 6.71 & 6.22 & 5.89 & 7.18 & 7.20 \\
$\mathrm{Na}_{2} \mathrm{O}$ & 0.02 & 0.02 & 0.00 & 0.01 & 0.02 & 0.05 & 0.01 & 0.01 & 0.02 & 0.02 & 0.03 & 0.04 & 0.02 & 0.06 \\
$\mathrm{Total}^{100.64}$ & 100.17 & 100.15 & 100.35 & 100.27 & 99.90 & 100.11 & 99.95 & 100.20 & 99.35 & 99.98 & 99.84 & 99.84 & 99.81 \\
\hline
\end{tabular}


of points on Sobolev's plot is located in the center of Iherzolitic trend) suggest low clinopyroxene content in primary Iherzolites. On the other hand, the low $\mathrm{Fe} /(\mathrm{Fe}+\mathrm{Mg})$ ratio and low amount of $\mathrm{TiO}_{2}$ in studied garnets imply the absence of mantle material, with an ilmenite-bearing paragenesis among the probable set of deep-seated xenoliths.

Thus, the available material indicates a Iherzolitic paragenesis which is, according to Sobolev's \& Pokhilenko's (Sobolev et al. 1997) opinion, a characteristic of non-diamondiferous and low diamondiferous pipes. Howerever, according to data of several authors (Barashkov \& Zudin 1997) inclusions of magnesian garnets in diamond may go beyond the field of duniteharzburgite paragenesis; in this case they fall in the field of Iherzolite paragenesis; the Krasnopresnenskaya (Yakutia), Star (South Africa) and Pomorskaya (Arkhangelsk region) pipes are such examples. Compositions of such garnets are similar to those of separate pyrope grains from the alluvium of the Chuksha and Tangui-Uda rivers.

Most pyropes from the present-day alluvial deposits and Chuksha rock formation of the Chuna-Birusa diamond-bearing area markedly differ in chemistry from magnesian garnets in alkaline basaltoids (Cheshskoiye highland, the Minusinsk ba$\sin$ ), in basic tuffaceous pipes of the Malaya-Botuobiya area, in explosion pipes of melilites, picrites, lamprophyres (Middle Timan), in picrite breccia (western slope of the North Ural) and in eruptive breccia of kimberlites (the Azov sea region). They are very similar in composition to diamond-bearing lamproitic veins of the Sayan submontane region (Ingashinskoye diamondiferous lamproitic field).

Additionally to accessory minerals of ultrabasic association, yellow-orange garnets of the pyrope-grossular-almandine series occur in heavy concentrates from diamond-bearing alluvial and terrace sediments and Chuksha rock formation (Table 2).

These garnets bear large similarities to garnets from eclogites of gneissic complexes of the North Muya block and the Kokchetav massif. They are characterized by significant grossular component (25.8-26.2 mol.\%) with a pyrope content not less than $12 \mathrm{~mol} \%$. The presence in the same concentrate samples of increased amounts of rutile suggests that the yelloworange pyrope-grossular-almandine garnets belong to the eclogite association. Rutiles are characterised by a stable admixture of $\mathrm{FeO}(0.2-1.0 \mathrm{wt} \%), \mathrm{Cr}_{2} \mathrm{O}_{3}$ (up to $0.22 \mathrm{wt} \%$ ) and $\mathrm{Al}_{2} \mathrm{O}_{3}(0.3-0.45$ wt \%).

Other garnets with analogous amount of grossular component are characterized by higher concentrations of $\mathrm{MnO}$ (3.76-3.91 wt \%). Garnets of similar composition occur among high-pressure magnesian associations of metabasites of the
Oka belt (Eastern Sayan), in eclogites of glaucophane-schist complexes (Atabashinsky ridge of the Tien Shan, Kirgizia) and glaucophane schists of the Clamat mountain (California). Temperatures of formation of manganese garnets are somewhat lower $\left(300-500^{\circ} \mathrm{C}\right)$ than those of the pyrope-grossularalmandine varieties.

Grossular with a small admixture of andradite (8.16-11.95 mol.\%) is predominant among calcic garnets from the Chuksha and Tangui-Uda rivers basin. Similar garnets are formed by metasomatism or contact metamorphism. Grossulars with low contents of andradite component are chemically close to garnets from exocontact of doleritic sill with the Krasnopresnenskaya kimberlite pipe (Shamshina $e t$ al., 1988). Andradite-grossular garnets compositionally similar to garnet from skarn iron ore deposits also occur.

Analyzed garnets of spessartine-almandine series from the Chuksha and Tangui-Uda rivers basins (Table 2) are characterized by larger range of concentrations for $\mathrm{FeO}$ (13.7924.55 wt \%), $\mathrm{MgO}(0.09-9.96 \mathrm{wt} \%)$ and $\mathrm{CaO}(1.84-8.08 \mathrm{wt}$ $\%)$. Content of $\mathrm{MnO}$ varies from 10.84 to $17.6 \mathrm{wt} \%$. The above spessartine-almandine garnets are compositionally similar to garnets from rare-metal and muscovite pegmatites and muscovite garnets. Other garnets are enriched in andradite and especially in grossular components (up to 19.3\%) and it should be noted here that the pyrope constituent increases distinctly and constitutes 4.1-5.8 mol.\%. Such garnets are typical for highly-metamorphosed rocks such as quartzites, sillimanite gneisses and gondites. There occur garnets with a peculiar composition characterized by a higher quantity of the pyrope component (38.0-38.2\%) in comparison with the almandine one (28.4-29.0\%). Garnets of similar composition occur in the highest-temperature rocks of granulite facies, for instance in viridine quartzites of the Aldan shield (Kulish, 1961).

Garnets with the high $\mathrm{Fe} /(\mathrm{Fe}+\mathrm{Mg})$ ratio $(85 \mathrm{~mol}$. \%) are very similar to garnets from biotite staurolite schists which are common in folded rocks of the Siberian platform.

Chrome spinellids of the Chuksha and Tangui-Uda rivers basins are analogous to chromites from kimberlites, lamproites and various xenoliths of mantle rocks according to $\mathrm{Cr}_{2} \mathrm{O}_{3}$ ' $\mathrm{Al}_{2} \mathrm{O}_{3}$ as well as $\mathrm{Cr}_{2} \mathrm{O}_{3} / \mathrm{TiO}_{2}$ ratios (Fig. 3).

$\mathrm{A}$ peculiarity of analyzed $\mathrm{Cr}$-spinellids is a relatively high $\mathrm{MnO}(0.4-1.19$ wt \%). The concentration of $\mathrm{MnO}$ in chromites from Yakutian kimberlites is usually less than 0.4-0.5 wt \%. Maximum $\mathrm{Cr}_{2} \mathrm{O}_{3}$ content in studied chrome spinellids reaches $63.5 \mathrm{wt} \%$.

Besides standard accessory minerals of diamond, garnets of goldmanite-uvarovite series with the first class of preservation,

Table 2 - Chemical composition of piralspitic garnets from alluvial deposits of the Chuksha and Tangui-Uda rivers (wt $\%)$

\begin{tabular}{|l|ccccccccccccccc}
\hline Pxides & 1 & 2 & 3 & 4 & 5 & 6 & 7 & 8 & 9 & 10 & 11 & 12 & 13 \\
\hline $\mathrm{SiO}_{2}$ & 37.68 & 38.10 & 38.29 & 37.58 & 38.04 & 36.01 & 39.58 & 37.58 & 39.46 & 37.89 & 36.55 & 37.98 & 39.54 \\
$\mathrm{TiO}_{2}$ & 0.00 & 0.25 & 0.25 & 0.02 & 0.02 & 0.70 & 0.72 & 0.38 & 0.37 & 0.46 & 0.04 & 0.00 & 0.00 \\
$\mathrm{Al}_{2} \mathrm{O}_{3}$ & 20.70 & 21.10 & 21.11 & 19.85 & 19.81 & 19.83 & 18.89 & 20.50 & 21.71 & 16.12 & 19.92 & 20.17 & 21.81 \\
$\mathrm{FeO}$ & 32.37 & 26.59 & 26.41 & 27.32 & 27.14 & 2.44 & 3.05 & 4.92 & 2.30 & 10.01 & 24.49 & 21.28 & 13.81 \\
$\mathrm{MgO}$ & 3.39 & 3.24 & 3.25 & 0.51 & 0.61 & 0.58 & 0.70 & 0.74 & 0.61 & 0.00 & 0.14 & 1.84 & 9.96 \\
$\mathrm{MnO}$ & 2.48 & 0.58 & 0.56 & 3.91 & 3.76 & 0.28 & 0.49 & 0.10 & 0.12 & 2.16 & 17.66 & 11.01 & 12.67 \\
$\mathrm{CaO}$ & 3.03 & 10.05 & 9.79 & 10.62 & 11.01 & 36.16 & 36.13 & 35.84 & 34.74 & 32.67 & 1.24 & 7.79 & 2.13 \\
$\mathrm{Na}_{2} \mathrm{O}$ & 0.00 & 0.02 & 0.03 & 0.03 & 0.03 & 0.00 & 0.03 & 0.00 & 0.00 & 0.01 & 0.04 & 0.02 & 0.01 \\
$\mathrm{Total}^{2}$ & 99.65 & 99.93 & 99.69 & 99.84 & 100.42 & 96.00 & 99.59 & 100.06 & 99.31 & 99.32 & 100.08 & 100.09 & 99.93 \\
\hline
\end{tabular}

1 - garnet of pyrope-almandine series; 2,3 - garnets of pyrope-grossular-almandine series; 4,5 - garnets of spessartine-grossular-almandine series; 6-10 - garnets of andradite-grossular series; $11-13$ - garnets of spessartine-almandine series. 
often in the form of tetragontrioctahedra with lustrous faces are found in alluvial deposits of the above rivers (Table 3 ).

It is not inconceivable that lamproitic rocks may be the primary sources of these garnets (by analogy with lamproitoids of the Sayan submontane region containing garnets of goldmanite-uvarovite series).

Lavrovites chemically identical to those from quartz-diopside rocks of the Slyudianka series of the Baikal region occur in alluvium of the Tangui-Uda River. It should be emphasized that lavrovites as well as garnets of goldmanite-uvarovite series are found within the Siberian platform for the first time.

Magnesian Al-spinels in association with calcic garnets along with gialosiderites, augites of two generations, Timagnetites and ilmenites (without $\mathrm{MgO}$ ) in increased quantities occur within areas where doleritic bodies and associated skarn formations are developed.

Thus, the typomorphic peculiarities of concentrate and mineralogical associations of the heavy fraction of the present alluvium of the Chuksha and Tangui-Uda river basins and the Lower Carboniferous deposits of the Chuksha rock formation are as follows: very low concentration of accessory minerals of diamond and of a small grain size (not more than 1.5-2.0 mm), good preservation of separate grains of chrome spinellids

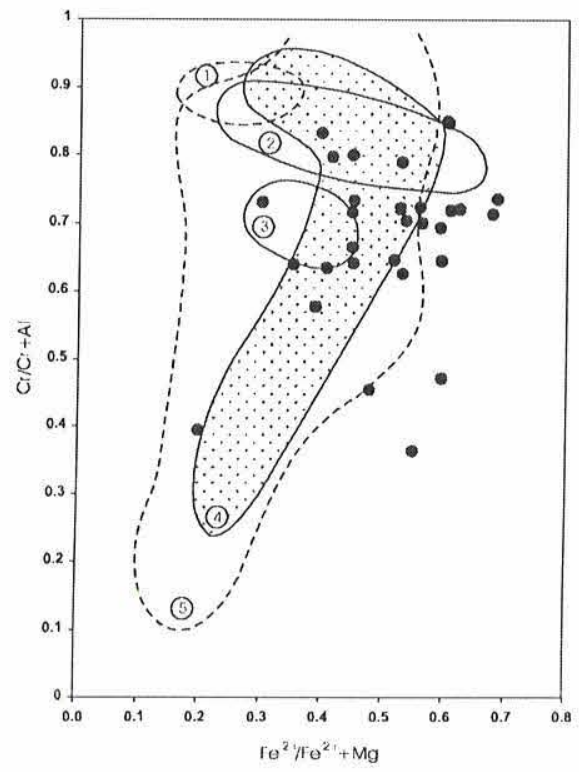

Figure 3 - Plots of chrome spinellids compositions from alluvial deposits of the Chuksha and Tangui-Uda rivers (filled circles) and from different genetic sources: I - inclusions in diamonds; 2 -meimechites; 3 -comatiites; 4 - kimberlite groundmass; 5 -xenoliths in kimberlites.
Table 3 - Chemical composition of garnets of goldmanite-uvarovire series (I -4) and lavrovites from alluvial deposits of the Chuksha and Tangui Uda rivers (wt \%)

\begin{tabular}{|c|cccccc|}
\hline Oxides & 1 & 2 & 3 & 4 & 5 & 6 \\
\hline $\mathrm{SiO}_{2}$ & 36.88 & 37.88 & 35.75 & 37.79 & 55.20 & 51.67 \\
$\mathrm{TiO}_{2}$ & 0.40 & 0.86 & 0.29 & 0.61 & 0.00 & 0.14 \\
$\mathrm{Al}_{2} \mathrm{O}_{3}$ & 15.22 & 16.96 & 9.34 & 11.69 & 0.54 & 2.72 \\
$\mathrm{Cr}_{2} \mathrm{O}_{3}$ & 0.70 & 2.55 & 6.93 & 5.58 & 0.18 & 1.01 \\
$\mathrm{~V}_{2} \mathrm{O}_{5}$ & 10.08 & 4.95 & 12.93 & 6.66 & 3.40 & 2.91 \\
$\mathrm{FeO}$ & 0.30 & 0.47 & 0.04 & 1.70 & 0.34 & 1.01 \\
$\mathrm{MnO}$ & 0.01 & 0.11 & 0.84 & 0.12 & 0.00 & 0.57 \\
$\mathrm{MgO}$ & 0.02 & 0.14 & 0.02 & 0.15 & 16.29 & 15.67 \\
$\mathrm{CaO}$ & 36.45 & 36.13 & 33.74 & 34.78 & 22.82 & 23.59 \\
$\mathrm{Na}_{2} \mathrm{O}$ & 0.00 & 0.00 & 0.00 & 0.06 & 1.45 & 1.14 \\
$\mathrm{Tolal}_{0}$ & 100.06 & 100.05 & 99.88 & 99.14 & 100.22 & 100.43 \\
\hline
\end{tabular}

(including those of diamond paragenesis). The presence of yellow-orange pyropes and garnets of the goldmanditeuvarovite series allow us to suggest occurrence of primary sources of diamonds. The highly diamondiferous effusive varieties of lamproitic rocks of the Australian type may represent such sources in the Chuna-Birusa region. High percentage of crystals with rhombododecahedral habit with traces of corrosion and graphitization is indirect evidence of this. Impoverished and non-contrasting aureoles of accessory minerals can also be formed in the process of erosion by water of crater facies volcanogenic sedimentary rocks, aphyric carbonatic varieties of kimberlites, composing the upper parts of pipes. Chrome spinellid is a basic indicator mineral in the above geological situations. So, taking into consideration the characteristics of potential diamondiferous formations in the region of the Angara-Chuna interfluve it is necessary to change the essential modes of concentrate-mineralogical method used for prospecting in the central areas of Yakutia. Mineralogical prospecting should be oriented to primary sources with very low contents and small sizes of accessory minerals. There is a need to study in detail the distribution, morphology and composition of unusual indicator minerals of heavy and light fractions of feasible diamond-bearing bodies. For example, the Sobolevskaya, Shchukinskaya and Bobkovskaya pipes (the Alakit kimberlite field) have been recently discovered in Western Yakutia according to concentration, size and degree of wear of almandine.

Acknowledgements This research was supported by the RFBR (02-05-65286). To two referees of RBg for suggestions to the manuscript.

\section{References}

Barashkov Yu.P. \& Zudin N.G. 1997. Composition of garnets with diamond inclusions from the Krasnopresnenskaya kimberlite pipe. Geologia and geofizika, 38:353-357.

Kharkiv A.D., Zinchuk N.N., Kruchkov A.I. 1995. Geologic-genetic bases for concentrate-mineralogical method of prospecting of diamond deposits. Moscow: Nauka. 348.

Kulish G.A. 1961. Manganese-aluminiferous rocks with the Archean viridine from the Aldan shield. Geologia and geofizika, 1:15-19)

Sobolev N.V., Yefimova E.S., Reimers L.F., Zakharchenko O.D., Markin A.I., Usova L.V.1997. Mineral inclusions in diamonds of the Arkhangelsk kimberlite province. Geologia and geofizika, 38: 358-370.

Shamshina E.A., Kruchkov A.I., Rogovoi V.V., Lelukh M.I., Zhikhareva V.P., Altukhova Z.A., Zolnikov G.V. 1988. Mineralogical peculiarities of kimberlitic rocks modified by influence of trappean sill. Topomineralogy and typomorphism of minerals / Yakutsk, Yakutian Branch of SD RAS, 4756.

Manuscrito A-1293

Recebido em 19 de novembro de 2001 Revisão dos autores em 05 de dezembro de 2001 Revisão aceita em 07 de dezembro de 2001 